\title{
Cyclopentadithiophene-based Co-oligomers for Solution-processed Organic Solar Cells
}

\author{
Rocío Domínguez, ${ }^{a}$ Gisela L. Schulz, ${ }^{\mathrm{b}}$ Pilar de la Cruz, ${ }^{\mathrm{a}}$ Peter Bäuerle*b and Fernando Langa*a \\ a University of Castilla-La Mancha, Institute for Nanoscience, Nanotechnology and Molecular Materials \\ (INAMOL), Campus de la Fábrica, 45071 Toledo, Spain. E-mail: fernando.langa@uclm.es \\ ${ }^{b}$ Institute of Organic Chemistry II and Advanced Materials, Ulm University, Albert-Einstein-Alle 11, 89081 \\ Ulm, Germany. E-mail: peter.baeuerle@uni-ulm.de
}

\section{ABSTRACT}

A new family of low band-gap co-oligomers based on $4 H$-cyclopenta[2,1-b:3,4- $\left.b^{\prime}\right]$ dithiophene (CPDT) and thieno[3,2-b]thiophene (TT) units as central electron-donor cores has been synthesized and characterized for use as electron-donor materials in solution-processed bulkheterojunction organic solar cells. An in-depth study into the role played by the hexyl chains linked to the thienylenevinylene-based $\pi$-bridge has been carried out. Power conversion efficiencies (PCE) of up to $4 \%$ and external quantum efficiencies as high as $50 \%$ have been achieved. Experiments carried out after solvent vapor annealing (SVA) as a post-treatment led to a doubling of the fill factor (FF) and PCE.

\section{Introduction}

Bulk heterojunction (BHJ) organic solar cells (OSCS) based on oligomers as electron-donor along with fullerene derivatives as electron-acceptor materials have been widely investigated in recent years owing to their excellent advantages, which include light weight, less marked batch to batch variations, high reproducibility, low-cost, flexibility and large-area applications [1]. Until now, BHJ OSCs based on $\pi$-conjugated oligomers, typically denoted as 'small molecules', have reached power conversion efficiencies (PCE) over 10\% [2], which is comparable to those of polymer-based OSCs [3]. П-Conjugated co-oligomers based on alternating electron-donor (D) and electron-acceptor (A) moieties lead to materials with outstanding properties, such as 
absorption in the visible to near-infrared region, strong charge transfer character, low highest occupied molecular orbital (HOMO)-lowest unoccupied molecular orbital (LUMO) energy gap, and good charge carrier mobility [4]. Of these materials, acceptor-donor-acceptor (A-D-A) oligomers are considered to be among the most promising molecular structures owing to their broad absorption, high hole mobility, suitable electronic levels, controlled solubility, and high open circuit voltage $\left(V_{O C}\right)$ of their resulting devices [5], and these have been extensively studied as donor materials in BHJ OSCs $[2 \mathrm{c}, 6]$.

Most of the research into the design of new A-D-A systems has been focused on optimization of the molecular structure of donors and acceptors. Regarding the donor fragments, fused aromatic rings have been widely used due to their extended $\pi$-conjugation, high charge carrier mobility, and reduced bandgap according to the enhancement of the $\pi$-electron delocalization [7]. The fused ring aromatic structures tend to form $\pi-\pi$ stacks with a large overlapping area and this leads to high charge carrier transport through intermolecular hopping, large crystalline domains, and more ordered domain boundaries. Additionally, the position and length of alkyl side chains on the central electron-donor building block play an important role for solubility, $\pi$ $\pi$ stacking, energy levels, and charge transport properties of the oligomers [8]. However, despite the fact that a great deal of effort has been focused on identifying structure-property relationships for these materials, their correlation with device performance parameters remains very difficult and several issues remain unresolved.

4H-Cyclopenta[2,1-b:3,4-b']dithiophene (CPDT) derivatives have recently been used in organic electronics and optical materials owing to their unique semiconducting and electronic properties, which include high electrical conductivity, low band-gap, and extended $\pi$ conjugation [9]. The fused-ring structure of CPDT, which is regarded as a fused-ring analogue of 3-alkylthiophene and a structural analogue of fluorene, has extended $\pi$-conjugation in the ground state due to the highly planar molecular geometry. This fused structure leads to a low 
reorganization energy, a parameter that affects the rate of intermolecular hopping and hence the charge carrier mobility in organic semiconductors. In addition, the increase in the degree of conjugation causes lower HOMO-LUMO separation, facilitates the intramolecular charge transfer process, and enables closer intermolecular interactions [10]. The chemical versatility of CPDT enables a relatively easy modification of the $\alpha$-positions by different functional groups and the introduction of alkyl substituents at the bridging carbon atom in order to improve the solubility. As a result, the fully coplanar structure and good electron-donating ability of CPDT have boosted its use as a building block in the preparation of electroactive conjugated polymers, especially narrow band gap $\pi$-conjugated polymers, as electron-donor materials, $\pi$-conjugated spacers, and as materials in organic photovoltaics [11].

Thieno[3,2-b]thiophene (TT) is also an aromatic fused ring system that is widely employed as a

55 key component in different molecular architectures [12] due to its symmetric configuration and high charge carrier mobility [13] originated from its high tendency to form strong intermolecular interactions and packing [14]. TT, a structure with two fused thiophene rings, exhibits excellent properties including a stable quinoidal structure and narrow energy band gap. Although the TT unit has been extensively employed in conjugated polymers to obtain high performance OPVs [15], it has rarely been used as a central electron-donor core in oligomers or 'small molecules' for solution-processed organic solar cells with high performance [16].

In the work described here, we have synthesized a new series of co-oligomers taking advantage of the outstanding properties displayed by the CPDT unit, i.e., fully planar structure and electronrich nature, and those exhibited by the $\Pi T$ structure. The synthesis and characterization of this new family of acceptor- $\pi$-donor- $\pi$-acceptor (A- $\pi-D-\pi-A)$ co-oligomers based on CPDT- (1-3) and TT-units (4) are described along with their use as electron-donor materials in solution-processed bulk-heterojunction solar cells (BHJSC). Dicyanovinylene (DCV) was used as the electronacceptor group and differently substituted thienylenevinylene (TV) moieties were employed as 
variation enabled a study of the effect of the alkyl chains on optical and electrochemical properties, morphology, and device performance parameters.

\section{Experimental section}

\subsection{Synthesis and characterization}

\subsubsection{General procedure for the Horner-Wadsworth-Emmons reaction}

In a round-bottomed flask, under an argon atmosphere, the corresponding phosphonate (2 eq) and the corresponding dialdehyde ( 1 eq) were dissolved in dry THF. ${ }^{\mathrm{B}} \mathrm{BuOK}(8 \mathrm{eq})$ was added and the mixture was stirred overnight at room temperature. After consumption of the dialdehyde (monitored by TLC), the crude product was extracted with diethyl ether. The organic phase was dried over $\mathrm{MgSO}_{4}$, concentrated in vacuo and purified by chromatography column (silica gel, hexane).

\subsubsection{Synthesis of (E,E)-2,6-Bis[2-(2-thienylvinyl)]-4,4-dihexyl-4H-cyclopenta[1,2-b:5,4- $\left.b^{\prime}\right]$ dithiophene (11)}

From $174 \mathrm{mg}$ of 8 [20] $(0.74 \mathrm{mmol})$ and $150 \mathrm{mg}$ of 5 [17] $(0.37 \mathrm{mmol})$ reacted as per the general procedure gave $200 \mathrm{mg}$ of $\mathbf{1 1}$ as red oil $\left(0.36 \mathrm{mmol}, 96 \%\right.$ yield). ${ }^{1} \mathrm{H}-\mathrm{NMR}\left(400 \mathrm{MHz}, \mathrm{CDCl}_{3}\right)$ 8/ppm: 7.18-7.17 (m, 2H), 7.04-7.00 (m, 8H), $6.88(\mathrm{~s}, 2 \mathrm{H}), 1.83-1.79(\mathrm{~m}, 4 \mathrm{H}), 1.16-1.14(\mathrm{~m}, 12 \mathrm{H}), 0.98$ (m, 4H), 0.84-0.81 (m, 6H); ${ }^{13} \mathrm{C}-\mathrm{NMR}\left(100 \mathrm{MHz}, \mathrm{CDCl}_{3}\right)$ /ppm: 158.8, 143.2, 142.8, 135.9, 127.7, 125.6, 124.0, 122.5, 120.8, 119.4, 53.8, 37.8, 31.6, 31.0, 29.7, 24.5, 22.6, 14.0; FT-IR (ATR) U/cm ${ }^{-}$ 1: 2924, 2850, 1416, 1392, 930, 852, 825, 686; UV-Vis $\left(\mathrm{CH}_{2} \mathrm{Cl}_{2}\right) \lambda_{\max } / \mathrm{nm}(\log \varepsilon): 460$ (4.66), 485 (4.62); $\mathrm{MS}\left(\mathrm{m} / \mathrm{z}\right.$ ) (MALDI-TOF): calculated $\mathrm{C}_{33} \mathrm{H}_{38} \mathrm{~S}_{4}$ : 562.19; found: $562.30\left(\mathrm{M}^{+}\right)$.

From $927 \mathrm{mg}$ of 6 [18] (2.30 mmol) and $226 \mathrm{mg}$ of 15 [22] (1.15 mmol) reacted as per the general procedure gave $230 \mathrm{mg}$ of 16 as an orange oil $\left(0.33 \mathrm{mmol}, 29 \%\right.$ yield). ${ }^{1} \mathrm{H}-\mathrm{NMR}$ ( $400 \mathrm{MHz}, \mathrm{CDCl}_{3}$ ) 
8/ppm: $7.09(\mathrm{~s}, 2 \mathrm{H}), 7.05\left(\mathrm{~d}, 2 \mathrm{H},{ }^{3} \mathrm{~J}=15.6 \mathrm{~Hz}\right), 6.99\left(\mathrm{~d}, 2 \mathrm{H},{ }^{3} \mathrm{~J}=15.6 \mathrm{~Hz}\right), 6.79(\mathrm{~s}, 2 \mathrm{H}), 2.64-2.60$ $(\mathrm{m}, 4 \mathrm{H}), 2.51-2.47(\mathrm{~m}, 4 \mathrm{H}), 1.70-1.59(\mathrm{~m}, 4 \mathrm{H}), 1.54-1.47(\mathrm{~m}, 4 \mathrm{H}), 1.40-1.32(\mathrm{~m}, 24 \mathrm{H}), 0.93-0.90$ (m, 12H); ${ }^{13} \mathrm{C}-\mathrm{NMR}\left(100 \mathrm{MHz}, \mathrm{CDCl}_{3}\right)$ 8/ppm: 145.2, 143.4, 140.7, 138.0, 136.2, 120.8, 120.6, 118.6, 118.0, 31.8, 31.6, 31.0, 29.6, 29.4, 29.3, 29.0, 27.0, 22.6, 14.1; FT-IR (KBr) U/cm ${ }^{-1}: 2954$, 2920, 2852, 1466, 922, 876, 831, 729; UV-Vis $\left(\mathrm{CH}_{2} \mathrm{Cl}_{2}\right) \lambda_{\max } / \mathrm{nm}(\log \varepsilon): 432$ (4.77), 457 (4.68); MS (m/z) (MALDI-TOF): calculated $\mathrm{C}_{42} \mathrm{H}_{60} \mathrm{~S}_{4}$ : 692.36; found: $692.91\left(\mathrm{M}^{+}\right)$.

\subsubsection{General procedure for the Vilsmeier-Haack formylation}

100 In a round-bottomed flask, under an argon atmosphere, $\mathrm{POCl}_{3}$ (4.5 eq) was added to a solution of the corresponding co-oligomer (1 eq) and DMF (6.3 eq) in dry DCE. The mixture was stirred overnight at room temperature. $1 \mathrm{M}$ aqueous sodium acetate solution was added to neutrality and then the mixture was stirred vigorously for $1 \mathrm{~h}$. The solution was extracted with dichloromethane and the organic phase was dried over $\mathrm{MgSO}_{4}$. After evaporation of the solvent, the product was purified by chromatography column (silica gel, hexane: $\mathrm{CHCl}_{3} 2: 3$ ).

\subsubsection{Synthesis of (E,E)-2,6-Bis[2-(5-formyl-2-thienylvinyl)]-4,4-dihexyl-4H-cyclopenta[1,2- $\left.b: 5,4-b^{\prime}\right] d i t h i o p h e n e(14)$}

$0.11 \mathrm{~mL}(1.20 \mathrm{mmol})$ of $\mathrm{POCl}_{3}$ were added to a solution of $150 \mathrm{mg}$ of $11(0.27 \mathrm{mmol})$ and 0.13 $\mathrm{mL}(1.68 \mathrm{mmol})$ of DMF in dry DCE $(25 \mathrm{~mL})$ under the same conditions as described in the general procedure. The dialdehyde 14 was obtained in $42 \%$ yield as a violet solid (71 mg, $0.11 \mathrm{mmol}$ ). ${ }^{1} \mathrm{H}-\mathrm{NMR}\left(400 \mathrm{MHz}, \mathrm{CDCl}_{3}\right)$ 8/ppm: $9.85(\mathrm{~s}, 2 \mathrm{H}), 7.66\left(\mathrm{~d}, 2 \mathrm{H},{ }^{3} \mathrm{~J}=3.8 \mathrm{~Hz}\right), 7.27\left(\mathrm{~d}, 2 \mathrm{H},{ }^{3} \mathrm{~J}=15.6 \mathrm{~Hz}\right)$, $7.10\left(\mathrm{~d}, 2 \mathrm{H},{ }^{3} \mathrm{~J}=3.8 \mathrm{~Hz}\right), 6.99\left(\mathrm{~d}, 2 \mathrm{H},{ }^{3} \mathrm{~J}=15.6 \mathrm{~Hz}\right), 7.01(\mathrm{~s}, 2 \mathrm{H}), 1.86-1.82(\mathrm{~m}, 4 \mathrm{H}), 1.21-1.14(\mathrm{~m}$, 12H), 0.98-0.94 (m, 4H), 0.84-0.81 (m, 6H); ${ }^{13} \mathrm{C}-\mathrm{NMR}\left(100 \mathrm{MHz}, \mathrm{CDCl}_{3}\right)$ 8/ppm: 182.4, 159.8, $152.4,143.0,141.1,137.8,137.5,126.8,126.2,122.8,118.5,54.0,37.8,31.6,29.7,24.5,22.6$, 14.0; FT-IR (KBr) U/cm ${ }^{-1}$ : 2951, 2926, 2852, 2794, 1651, 1597, 1522, 1448, 1387, 1228, 1047, 924, 822, 667; UV-Vis $\left(\mathrm{CH}_{2} \mathrm{Cl}_{2}\right) \lambda_{\max } / \mathrm{nm}(\log \varepsilon): 512$ (4.77); MS (m/z) (MALDI-TOF): calculated $\mathrm{C}_{35} \mathrm{H}_{38} \mathrm{O}_{2} \mathrm{~S}_{4}: 618.18$; found: $618.28\left(\mathrm{M}^{+}\right)$. 
2.1.6 Synthesis of (E,E)-2,5-Bis[2-(5-formyl-3,4-dihexyl-2-thienylvinyl)] thieno[3,2-b]thiophene (17)

$0.10 \mathrm{~mL}(1.14 \mathrm{mmol})$ of $\mathrm{POCl}_{3}$ were added to a solution of $175 \mathrm{mg}$ of $16(0.25 \mathrm{mmol})$ and 0.12 $\mathrm{mL}(1.59 \mathrm{mmol})$ of DMF in dry DCE $(25 \mathrm{~mL})$ under the same conditions as described in the general procedure. The dialdehyde 17 was obtained in $69 \%$ yield as a red solid $\left(130 \mathrm{mg}, 0.17 \mathrm{mmol}\right.$ ). ${ }^{1} \mathrm{H}$ -

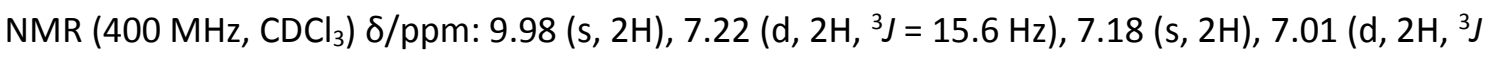
$=15.6 \mathrm{~Hz}), 2.86-2.82(\mathrm{~m}, 4 \mathrm{H}), 2.64-2.60(\mathrm{~m}, 4 \mathrm{H}), 1.60-1.57(\mathrm{~m}, 4 \mathrm{H}), 1.54-1.49(\mathrm{~m}, 4 \mathrm{H}), 1.42-$ $1.32(\mathrm{~m}, 24 \mathrm{H}), 0.94-0.89(\mathrm{~m}, 12 \mathrm{H}) ;{ }^{13} \mathrm{C}-\mathrm{NMR}\left(100 \mathrm{MHz}, \mathrm{CDCl}_{3}\right)$ 8/ppm: 181.8, 152.8, 145.8, 145.2, $142.4,139.3,135.3,125.2,120.2,119.5,32.3,31.5,31.2,29.4,39.3,27.2,26.4,22.6,22.5,14.1$, 14.0; FT-IR (KBr) U/cm ${ }^{-1}:$ 2953, 2922, 2854, 1635, 1591, 1433, 1406, 1373, 1304, 1246, 1124, 945, 848; UV-Vis $\left(\mathrm{CH}_{2} \mathrm{Cl}_{2}\right) \lambda_{\max } / \mathrm{nm}$ ( $\left.\log \varepsilon\right): 474$ (4.91); MS (m/z) (MALDI-TOF): calculated $\mathrm{C}_{44} \mathrm{H}_{60} \mathrm{O}_{2} \mathrm{~S}_{4}: 748.35$; found: $749.00\left(\mathrm{M}^{+}\right)$.

\subsubsection{General procedure for the Knoevenagel reaction}

In a round-bottomed flask, under an argon atmosphere, three drops of $\mathrm{Et}_{3} \mathrm{~N}$ were added to a solution of malononitrile ( 3 eq) and the corresponding dialdehyde ( 1 eq) in $\mathrm{CHCl}_{3}$. The reaction mixture was stirred overnight at room temperature and treated with brine after consumption of the bisaldehyde (monitored by TLC). The organic phase was dried over $\mathrm{MgSO}_{4}$ and the solid obtained by evaporation of the solvent under reduced pressure was purified by chromatography column (silica gel, hexane: $\mathrm{CHCl}_{3} 2: 3$ ) and recrystallization from $\mathrm{MeOH}$ and hexane.

\subsubsection{Synthesis of 1}

$380 \mathrm{mg}(0.40 \mathrm{mmol})$ of 12 [21], $79 \mathrm{mg}(1.19 \mathrm{mmol})$ of malononitrile and three drops of $\mathrm{Et}_{3} \mathrm{~N}$ were stirred in $\mathrm{CHCl}_{3}(50 \mathrm{~mL})$ under the conditions described in the general procedure. The product 1 was obtained in $68 \%$ yield (287 mg, $0.27 \mathrm{mmol}) .{ }^{1} \mathrm{H}-\mathrm{NMR}\left(400 \mathrm{MHz}, \mathrm{CDCl}_{3}\right)$ 8/ppm: $7.76(\mathrm{~s}, 2 \mathrm{H})$, $7.36\left(\mathrm{~d}, 2 \mathrm{H},{ }^{3} \mathrm{~J}=15.6 \mathrm{~Hz}\right), 7.05(\mathrm{~s}, 2 \mathrm{H}), 7.00\left(\mathrm{~d}, 2 \mathrm{H},{ }^{3} \mathrm{~J}=15.6 \mathrm{~Hz}\right), 2.69-2.62(\mathrm{~m}, 8 \mathrm{H}), 1.88-1.84(\mathrm{~m}$, $4 \mathrm{H}), 1.51-1.34(\mathrm{~m}, 30 \mathrm{H}), 1.26-1.18(\mathrm{~m}, 12 \mathrm{H}), 1.01-0.91(\mathrm{~m}, 18 \mathrm{H}), 0.85-0.82(\mathrm{~m}, 6 \mathrm{H}) ;{ }^{13} \mathrm{C}-\mathrm{NMR}$ 
(100 MHz, $\mathrm{CDCl}_{3}$ ) $\delta / \mathrm{ppm}: 160.6,156.0,149.3,147.1,143.9,141.1,138.5,128.3,128.2,123.6$, $116.4,115.6,114.4,72.8,54.1,37.6,32.2,31.6,31.5,31.0,29.6,29.4,29.3,27.8,26.8,24.6$, 22.6, 22.6, 22.5, 14.1, 14.0; FT-IR (KBr) U/cm ${ }^{-1}:$ 2954, 2929, 2856, 2218, 1587, 1560, 1402, 1286, 1161, 1086, 920; UV-Vis $\left(\mathrm{CH}_{2} \mathrm{Cl}_{2}\right) \lambda_{\max } / \mathrm{nm}$ (log $\left.\varepsilon\right): 645$ (5.03); MS (m/z) (MALDI-TOF): calculated $\mathrm{C}_{65} \mathrm{H}_{86} \mathrm{~N}_{4} \mathrm{~S}_{4}: 1050.57$; found: $1051.65\left(\mathrm{M}^{+}\right)$. MP (DSC): $284^{\circ} \mathrm{C}$.

\subsubsection{Synthesis of 2}

$144 \mathrm{mg}(0.18 \mathrm{mmol})$ of 13 [21], $36 \mathrm{mg}(0.55 \mathrm{mmol})$ of malononitrile and three drops of $\mathrm{Et}_{3} \mathrm{~N}$ were 150 stirred in $\mathrm{CHCl}_{3}(25 \mathrm{~mL})$ under the conditions described in the general procedure. The product 2 was obtained in $86 \%$ yield (139 mg, $0.16 \mathrm{mmol}) .{ }^{1} \mathrm{H}-\mathrm{NMR}\left(400 \mathrm{MHz}, \mathrm{CDCl}_{3}\right) \delta / \mathrm{ppm}: 7.67(\mathrm{~s}, 2 \mathrm{H})$, $7.43(\mathrm{~s}, 2 \mathrm{H}), 7.33\left(\mathrm{~d}, 2 \mathrm{H},{ }^{3} \mathrm{~J}=15.6 \mathrm{~Hz}\right), 7.05(\mathrm{~s}, 2 \mathrm{H}), 6.98\left(\mathrm{~d}, 2 \mathrm{H},{ }^{3} \mathrm{~J}=15.6 \mathrm{~Hz}\right), 2.68\left(\mathrm{t}, 4 \mathrm{H},{ }^{3} \mathrm{~J}=7.5\right.$ $\mathrm{Hz}), 1.88-1.84(\mathrm{~m}, 4 \mathrm{H}), 1.65-1.57(\mathrm{~m}, 4 \mathrm{H}), 1.38-1.33(\mathrm{~m}, 12 \mathrm{H}), 1.24-1.15(\mathrm{~m}, 16 \mathrm{H}), 0.93-0.90$ (m, 6H), 0.85-0.81 (m, 6H); ${ }^{13} \mathrm{C}-\mathrm{NMR}\left(100 \mathrm{MHz}, \mathrm{CDCl}_{3}\right)$ 8/ppm: 160.5, 149.8, 149.5, 143.8, 142.2, $141.7,138.5,131.8,128.1,123.5,116.1,114.8,113.9,74.7,54.1,37.6,31.6,31.5,30.5,29.6$ 28.9, 28.0, 24.6, 22.6, 22.5, 14.1, 14.0; FT-IR (KBr) U/ $\mathrm{cm}^{-1}:$ 2956, 2928, 2856, 2220, 1589, 1568, 1431, 922; UV-Vis $\left(\mathrm{CH}_{2} \mathrm{Cl}_{2}\right) \lambda_{\max } / \mathrm{nm}(\log \varepsilon): 642$ (4.97); MS (m/z) (MALDI-TOF): calculated $\mathrm{C}_{53} \mathrm{H}_{62} \mathrm{~N}_{4} \mathrm{~S}_{4}: 882.39$; found: $882.51\left(\mathrm{M}^{+}\right)$. MP (DSC): $269^{\circ} \mathrm{C}$.

\subsubsection{Synthesis of 3}

$80 \mathrm{mg}(0.40 \mathrm{mmol})$ of $14,26 \mathrm{mg}(0.39 \mathrm{mmol})$ of malononitrile and three drops of $\mathrm{Et}_{3} \mathrm{~N}$ were stirred in $\mathrm{CHCl}_{3}(15 \mathrm{~mL})$ under the conditions described in the general procedure. The product 3 was obtained as a dark blue solid in $66 \%$ yield (61 mg, $0.085 \mathrm{mmol}) .{ }^{1} \mathrm{H}-\mathrm{NMR}\left(500 \mathrm{MHz}, \mathrm{TCE}-\mathrm{D}_{2}\right.$ )

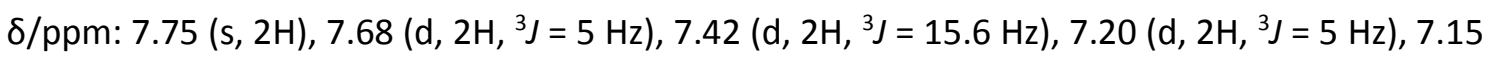
$(\mathrm{s}, 2 \mathrm{H}), 7.08\left(\mathrm{~d}, 2 \mathrm{H},{ }^{3} \mathrm{~J}=15.6 \mathrm{~Hz}\right), 1.95-1.92(\mathrm{~m}, 4 \mathrm{H}), 1.32-1.24(\mathrm{~m}, 12 \mathrm{H}), 1.11(\mathrm{~m}, 4 \mathrm{H}), 0.93-0.90$

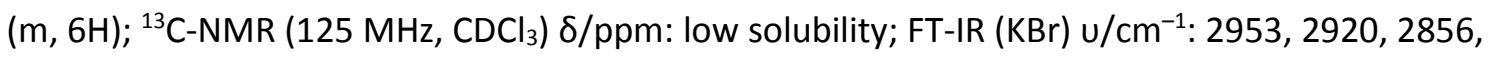
2218, 1593, 1568, 1439, 1383, 1055, 926, 829; UV-Vis $\left(\mathrm{CH}_{2} \mathrm{Cl}_{2}\right) \lambda_{\max } / \mathrm{nm}(\log \varepsilon)$ : 630 (4.94); MS (m/z) (MALDI-TOF): calculated $\mathrm{C}_{41} \mathrm{H}_{38} \mathrm{~N}_{4} \mathrm{~S}_{4}:$ : 714.20; found: $714.30\left(\mathrm{M}^{+}\right)$. 


\subsubsection{Synthesis of 4}

$130 \mathrm{mg}(0.17 \mathrm{mmol})$ of $17,34 \mathrm{mg}(0.52 \mathrm{mmol})$ of malononitrile and three drops of $\mathrm{Et}_{3} \mathrm{~N}$ were stirred in $\mathrm{CHCl}_{3}(22 \mathrm{~mL})$ under the conditions described in the general procedure. The product 4 was obtained as a purple solid in $75 \%$ yield $(110 \mathrm{mg}, 0.13 \mathrm{mmol}) .{ }^{1} \mathrm{H}-\mathrm{NMR}(500 \mathrm{MHz}$, TCE-D $)$

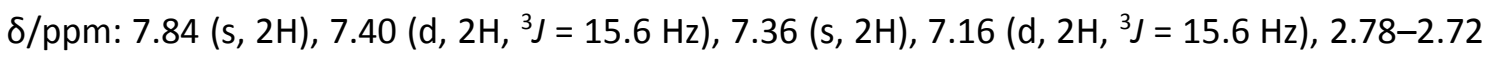
$(\mathrm{m}, 8 \mathrm{H}), 1.66-1.57(\mathrm{~m}, 8 \mathrm{H}), 1.53-1.48(\mathrm{~m}, 8 \mathrm{H}), 1.46-1.41(\mathrm{~m}, 16 \mathrm{H}), 1.02-0.99(\mathrm{~m}, 12 \mathrm{H}) ;{ }^{13} \mathrm{C}-\mathrm{NMR}$ (125 MHz, $\mathrm{CDCl}_{3}$ ) 8/ppm: 155.8, 148.0, 147.3, 145.6, 142.3, 140.6, 128.9, 127.5, 120.9, 119.3, $115.3,114.1,74.5,31.9,31.5,31.4,30.9,29.3,29.2,27.9,27.0,22.5,22.4,13.9,13.8 ; \mathrm{FT}-\mathrm{IR}$ (KBr) U/cm ${ }^{-1}: 2956,2924,2854,2220,1599,1564,1464,1406,1338,1159,1082,926,802,690$; UVVis $\left(\mathrm{CH}_{2} \mathrm{Cl}_{2}\right) \lambda_{\max } / \mathrm{nm}$ (log $\varepsilon$ ): 566 (5.02); MS (m/z) (MALDI-TOF): calculated $\mathrm{C}_{50} \mathrm{H}_{60} \mathrm{~N}_{4} \mathrm{~S}_{4}: 844.37$; found: $844.60\left(\mathrm{M}^{+}\right)$. MP (DSC): $212^{\circ} \mathrm{C}$.

\subsection{Device fabrication and characterization}

Photovoltaic devices were made by spin-coating PEDOT:PSS (Clevios P, VP Al4083) onto precleaned, patterned indium tin oxide (ITO) substrates (17-20 $\Omega$ per square) (Naranjo). The photoactive layer $(\sim 80 \mathrm{~nm})$ was deposited by spin-coating from of a mixed solution of donor with $\mathrm{PC}_{61} \mathrm{BM}$ (total concentration of $15 \mathrm{mg} \mathrm{mL}^{-1}$ in chloroform or tetrachloroethane) at room temperature. $\mathrm{PC}_{61} \mathrm{BM}$ was purchased from Solenne BV, Netherlands. The counter electrode of LiF $(1 \mathrm{~nm})$ and aluminum (100 nm) was deposited by vacuum evaporation at $2 \times 10^{-6}$ Torr. The active areas of the cells were $0.09 \mathrm{~cm}^{2}$ or $0.16 \mathrm{~cm}^{2}$. Film thicknesses were measured using a Dektak profilometer. J-V characteristics were measured under AM $1.5 \mathrm{G}$ conditions at 100 $\mathrm{mW} / \mathrm{cm}^{2}$ with a AAA solar simulator from Oriel Instruments, using a Keithley 2400 source meter. Spectral response was measured under monochromatic light from a $300 \mathrm{~W}$ Xenon lamp in combination with monochromator (Oriel, Cornerstone 260), modulated with a mechanical chopper. The response was recorded as the voltage over a $220 \Omega$ resistance, using a lock-in amplifier (Merlin 70104). A calibrated Si cell was used as reference. 


\section{Results and discussion}

\subsection{Synthesis and thermal properties}

195 The synthesis of novel A-D-A-type systems 1-4 is shown in Schemes 1 and 2. HornerWadsworth-Emmons reaction of dialdehyde 5 [17] with the corresponding phosphonates 6 [18], 7 [19], and 8 [20] afforded central building blocks 9 [21], 10 [21], and 11 as trans-isomers according to NMR spectra $\left({ }^{3}{ }_{\text {trans }}=15.6 \mathrm{~Hz}\right)$. Subsequent Vilsmeier-Haack formylation led to the corresponding dialdehydes 12 [21], 13 [21], and 14 after purification by chromatography column. Finally, Knoevenagel condensation of 12-14 with malononitrile under basic conditions $\left(\mathrm{Et}_{3} \mathrm{~N}\right)$ afforded target oligomers 1-3 in good yields. The synthetic route for the preparation of derivative 4 was similar, but dialdehyde 15 [22] and phosphonate 6 were used in the HornerWadsworth-Emmons reaction. Subsequent Vilsmeier-Haack formylation and Knoevenagel reaction yielded the final product $\mathbf{4}$ after purification by chromatography column and recrystallization from methanol (Scheme 2). All new compounds were characterized by ${ }^{1} \mathrm{H}-\mathrm{NMR}$, ${ }^{13} \mathrm{C}-\mathrm{NMR}, \mathrm{FT}-\mathrm{IR}$, and MALDI-TOF MS analysis and the results confirmed the expected structures (see Supporting Information). 


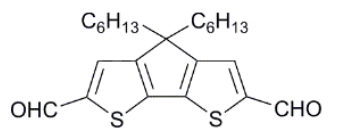

5

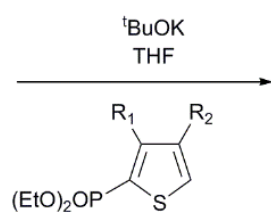

6: $\mathrm{R}_{1}=\mathrm{R}_{2}=\mathrm{C}_{6} \mathrm{H}_{13}$

7: $\mathrm{R}_{1}=\mathrm{C}_{6} \mathrm{H}_{13} ; \mathrm{R}_{2}=\mathrm{H}$

8: $R_{1}=R_{2}=H$

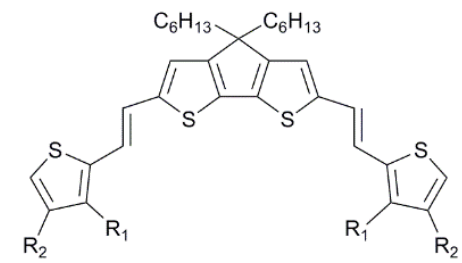

9: $\mathrm{R}_{1}=\mathrm{R}_{2}=\mathrm{C}_{6} \mathrm{H}_{13}$ 10: $\mathrm{R}_{1}=\mathrm{C}_{6} \mathrm{H}_{13} ; \mathrm{R}_{2}=\mathrm{H}$ 11: $R_{1}=R_{2}=H$
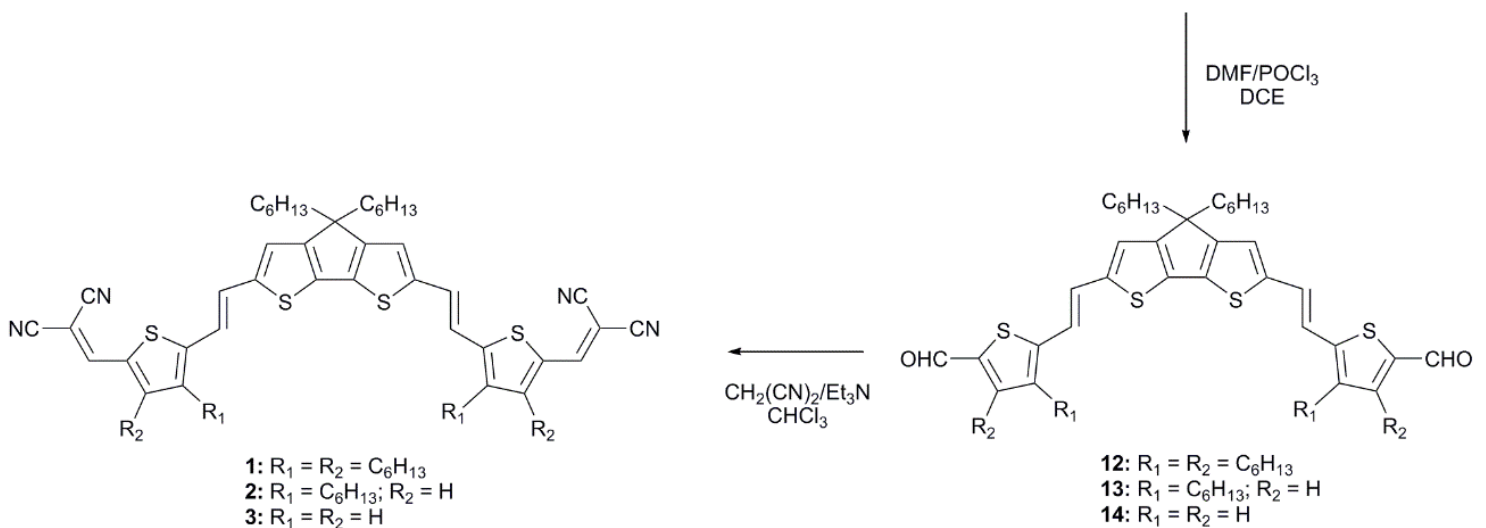

Scheme 1. Synthesis of co-oligomers 1-3.

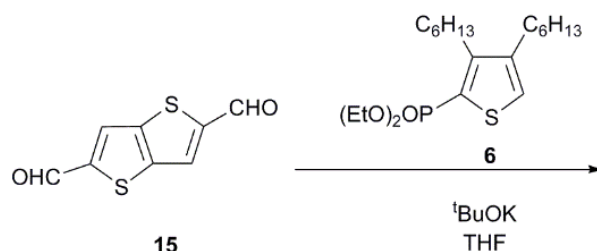

15

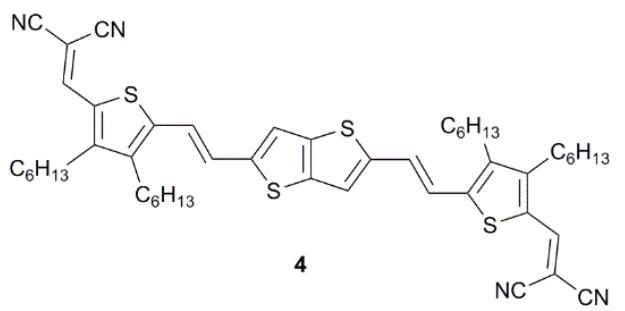

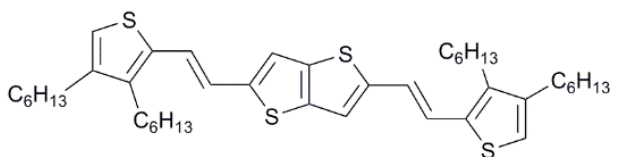

16 $\mathrm{DMF} / \mathrm{POCl}_{3}$ DCE

Scheme 2. Synthesis of co-oligomer 4.

Decomposition $(T d)$ and melting $(T m)$ temperatures of derivatives 1-4 were investigated by thermogravimetric analysis (TGA) (Figure 1 (top)) and differential scanning calorimetry (DSC) (Figure 1 (bottom)), respectively, under a nitrogen atmosphere at a heating rate of $10{ }^{\circ} \mathrm{C} \mathrm{min}^{-1}$. TGA measurements confirmed the high thermal stability of the novel A-D-A systems, as evidenced by $\mathrm{Td}$ values of $350{ }^{\circ} \mathrm{C}$ for $1,340{ }^{\circ} \mathrm{C}$ for $2,340{ }^{\circ} \mathrm{C}$ for 3 , and $355^{\circ} \mathrm{C}$ for 4 determined from the onset value of the degradation process. Removal of the hexyl side chains decreased 
the melting point from $284{ }^{\circ} \mathrm{C}$ (compound 1) to $269{ }^{\circ} \mathrm{C}(2)$ indicating weaker intermolecular interactions in the solid state. In the case of co-oligomer 3, a peak was not observed in the DSC trace due to either glass transition temperatures, a melting point, or crystallization. This finding indicates that $\mathbf{3}$ has amorphous properties, at least by the experiments carried out via standard DSC.

Two endothermic peaks due to a solid-solid phase transition and a melting transition at around $148^{\circ} \mathrm{C}$ and $212{ }^{\circ} \mathrm{C}$, respectively, were observed in the heating trace of derivative 4 . The melting point of this co-oligomer is lower than those of $\mathbf{1}$ and $\mathbf{2}$, which means poorer intermolecular interactions of the TT-based co-oligomer in the solid state. The thermal stability of oligomers 14 is sufficiently high to allow photovoltaic device fabrication.
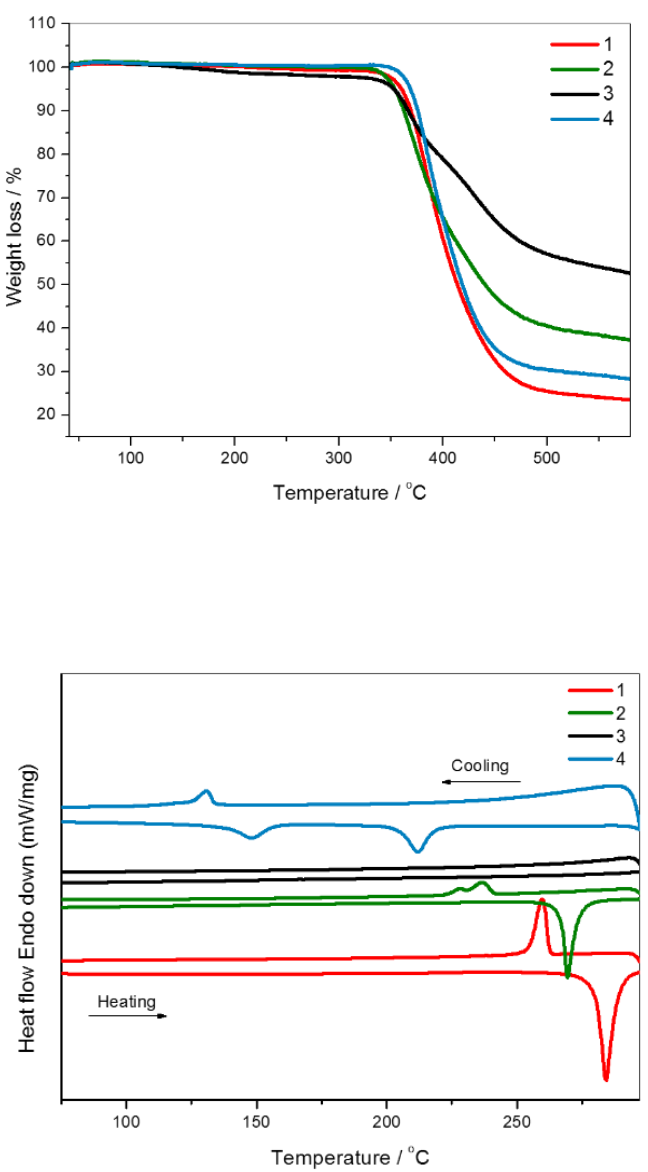
Fig. 1. (top) TGA traces of co-oligomers 1-4 measured under $\mathrm{N}_{2}$ flow at a heating rate of $10 \stackrel{\circ}{ } \mathrm{min}^{-1}$ and (bottom) DSC traces of co-oligomers 1-4 measured under $\mathrm{N}_{2}$ flow at a heating rate of $20 \stackrel{\circ}{ } \mathrm{min}^{-1}$ and a

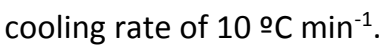

\subsection{Optical and electrochemical properties}

230

The absorption properties of co-oligomers 1-4 were investigated by UV-vis spectroscopy. The UV-vis spectra in dilute dichloromethane solution $\left(c \approx 10^{-6} \mathrm{M}\right)$ are displayed in Figure 2 (top) and the most relevant optical properties are summarized in Table 1. The A-D-A co-oligomers 1-3, which bear CPDT as a donor moiety, exhibited a broad, intense absorption band with maxima at 645,642 , and $630 \mathrm{~nm}$, respectively, while molecule 4 showed an absorption maximum at $\lambda_{\max }=$ $566 \mathrm{~nm}$; these broad bands are attributed to an intramolecular charge-transfer transition from the oligomer backbone to the terminal electron-accepting DCV. Remarkably, a substantial blueshift of the absorption maximum is observed for derivative $\mathbf{4}$ compared with chromophores 13 and this can be explained by the decreased conjugation length in the A-D-A structures. All derivatives showed a second, weaker absorption band in the UV region at 350-400 $\mathrm{nm}$ due to the $\pi-\pi^{*}$ transition of the conjugated system. All chromophores exhibited significantly high molecular absorption coefficients, values up to $\log \varepsilon=5.03$ were obtained.

In thin films, oligomers 1, 2, and $\mathbf{4}$ displayed two different absorption maxima at 658 and 720 nm, 664 and $725 \mathrm{~nm}$, and 614 and $663 \mathrm{~nm}$, respectively (Figure 2 (bottom)). These two absorption bands, along with a shoulder at higher energy, indicate the presence of $\mathrm{H}$ - and $\mathrm{J}$ aggregates in the solid state. Deconvolution of the UV-vis spectra in thin films can provide an insight into the contribution of individual molecules (absorption band at similar $\lambda$ to that in solution) and $\mathrm{H}$ - (absorption band shifted to higher energies) and J- (absorption band shifted to lower energies) aggregates [23], with the contribution of J-aggregates being more pronounced in co-oligomers 1, 2 and $\mathbf{4}$ (Figures S32-35, Supporting Information). In the case of co-oligomer 3, a $40 \mathrm{~nm}$ red-shift and a broadening of the main absorption band was observed in thin films, probably due to the lower contribution of $\mathrm{H}$ - and J-aggregates with respect to those in 
derivatives $\mathbf{1}, \mathbf{2}$, and $\mathbf{4}$. The presence of these aggregates can be attributed to co-planarization and ordering of the molecules in the bulk and this suggests good packing in thin films.

The emission spectra of co-oligomers $1-4$ measured in dichloromethane solution $\left(\mathrm{c} \approx 10^{-6} \mathrm{M}\right.$ ) are depicted in Figure S36 (Supporting Information). In a similar way to the absorption spectra, the emission maxima were shifted bathochromically upon elongation of the $\pi$-system (Table 1 ), from $664 \mathrm{~nm}$ for $T$ T-based co-oligomer 4 to $754 \mathrm{~nm}$ for $\mathbf{1}, 759 \mathrm{~nm}$ for $\mathbf{2}$, and $744 \mathrm{~nm}$ for $\mathbf{3}$ (CPDTbased derivatives). All molecules showed relatively similar and large Stokes shifts between 2241 $\mathrm{cm}^{-1}$ and $2608 \mathrm{~cm}^{-1}$ (Table 1). These values are consistent with substantial differences in the geometry, electron distribution, and molecular dipole moment between the ground and excited state. Co-oligomer 4 (TT-based derivative) exhibited the largest Stokes shift $\left(2608 \mathrm{~cm}^{-1}\right)$ within this family.

Electrochemical measurements were carried out in order to determine HOMO and LUMO energy levels. Cyclic voltammetry (CV) and Osteryoung square wave voltammetry (OSWV) experiments were carried out in a three-electrode configuration in Ortho-

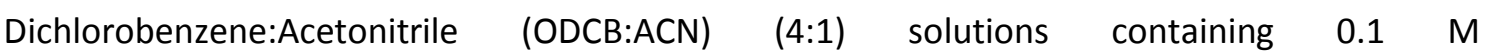
tetrabutylammonium perchlorate as supporting electrolyte. The data are presented in Figures S37-45 (Supporting Information) and are summarized in Table 1. 

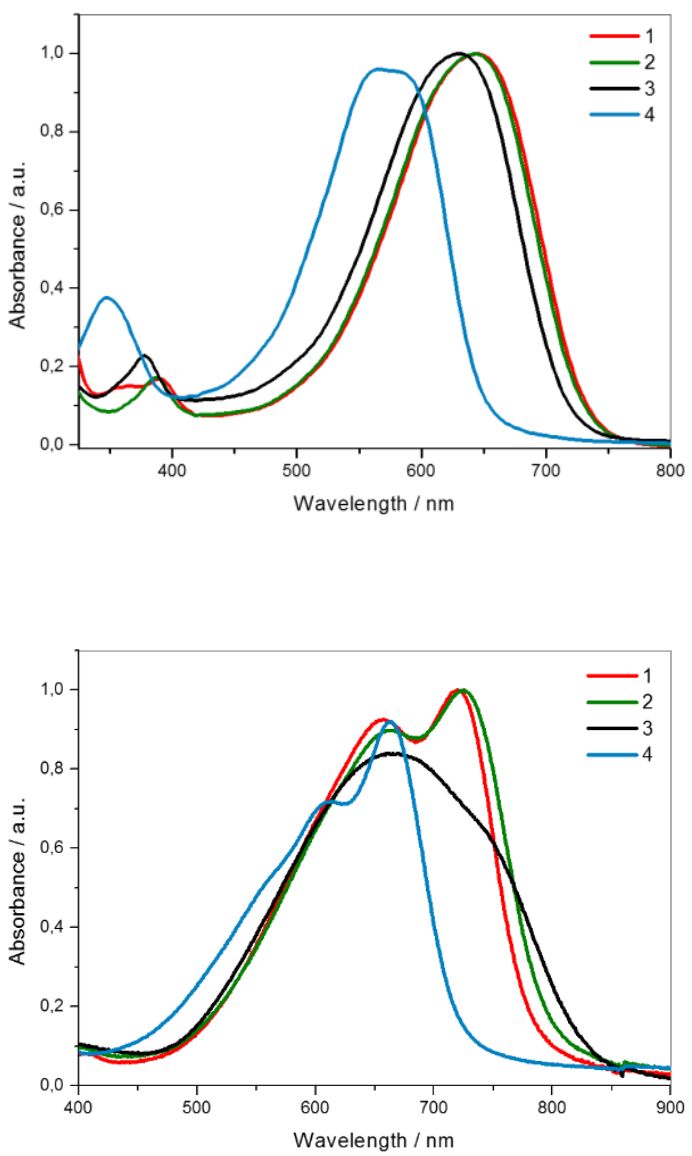

Fig. 2. UV-Vis absorption spectra of co-oligomers 1-4 in (top) dichloromethane solution (c $\approx 10^{-6} \mathrm{M}$ ) and (bottom) thin films deposited by spin-coating on glass substrates.

CPDT-based derivatives 1-3 showed two reversible and one irreversible one-electron oxidation $\left(3 \times 1 e^{-}\right)$processes within the accessible electrochemical window. The first two processes are assigned to the formation of stable radical cations and dications of the central thiophene-based co-oligomer. In contrast, compound $\mathbf{4}$ exhibited three irreversible oxidation waves and these are also ascribed to the stepwise oxidation of the oligomer core. Compared to molecules $1-3$, the replacement of CPDT by a $T T$ unit in 4 resulted in an increase in the oxidation potential from $0.32-0.34 \mathrm{~V}$ to $0.58 \mathrm{~V}\left(\mathrm{vs}\right.$. $\left.\mathrm{Fc} / \mathrm{Fc}^{+}\right)$, respectively, as a consequence of the decrease in conjugation. In the negative potential regime, all co-oligomers (1-4) showed a reduction process at around$1.30 \mathrm{~V} v s . \mathrm{Fc} / \mathrm{Fc}^{+}$assigned to the reduction of the terminal DCV groups. In contrast to the effect seen in the oxidation window, the reduction potential is affected to a lesser degree by the 
extension of the $\pi$-conjugated system, and it remains practically unaltered in the CPDT- and TTbased oligomers because the negative charges are rather localized on the electron-withdrawing DCV acceptor groups.

The electrochemical data were transformed into HOMO and LUMO energy levels vs. vacuum (Figure 3); the frontier molecular orbitals (FMO) were calculated from the first oxidation and reduction potentials, respectively, with the ferrocene HOMO energy set to $-5.1 \mathrm{eV} v s$. vacuum (Table 1) [24]. The HOMO and LUMO energy levels of CPDT-based oligomers 1-3 were found to be around $-5.4 \mathrm{eV}$ and $-3.8 \mathrm{eV}$, respectively, and they are essentially unaltered by the nature of the substitution on the thiophene rings. A decrease in the HOMO energy level was observed for TT-based oligomer 4, concomitant with the reduction of the $\pi$-conjugation by one double bond, and this is consistent with the trend previously observed for the absorption maxima. Due to both, the relatively low-lying HOMO and the low LUMO energy values, which are around -3.80 $\mathrm{eV}$, co-oligomers 1-4 should be suitable as donor and $p$-type semiconducting materials in organic solar cells using fullerene derivatives as acceptors. Chromophores 1-3 have a smaller band gap of around $1.6 \mathrm{eV}$ and this would be expected to give a good light absorption in the visible-nir region. In contrast, the low values for the HOMOs should be beneficial in providing a higher $V_{o c}$ for the resultant BHJ OSC; derivative $\mathbf{4}$ should afford the highest open circuit voltage $\left(V_{O c}\right)$ in solar cells because it has the deepest HOMO energy level. 
Optical and electrochemical data for chromophores 1-4.

\begin{tabular}{|c|c|c|c|c|c|c|c|c|c|c|c|}
\hline & $\begin{array}{c}\lambda_{\mathrm{abs}} \\
(\mathrm{nm})^{\mathrm{a}} \\
\text { sol }\end{array}$ & $\log \varepsilon$ & $\begin{array}{c}\lambda_{\text {abs }} \\
(n m) \\
\text { film } \\
\end{array}$ & $\begin{array}{c}\lambda_{\text {em }} \\
(\mathrm{nm})^{\mathrm{b}} \\
\text { sol }\end{array}$ & $\begin{array}{c}\text { Stokes } \\
\text { shift } \\
\left(\mathrm{cm}^{-1}\right) \\
\end{array}$ & $\begin{array}{l}\text { Solubility } \\
\text { in } \mathrm{CHCl}_{3} \\
\left(\mathrm{mg} \mathrm{mL}^{-1}\right)\end{array}$ & $\begin{array}{l}E_{o \times 1} \\
(V)^{c}\end{array}$ & $\begin{array}{l}E_{\text {red1 }} \\
(V)^{c}\end{array}$ & $\begin{array}{l}\text { HOMO } \\
(e V)^{d}\end{array}$ & $\begin{array}{l}\text { LUMO } \\
(\mathrm{eV})^{\mathrm{d}}\end{array}$ & $\begin{array}{l}E_{\mathrm{g}}^{\text {elec }} \\
(\mathrm{eV})^{\mathrm{e}}\end{array}$ \\
\hline 1 & 645 & 5.03 & $\begin{array}{l}658 \\
720\end{array}$ & 754 & 2241 & 66 & 0.32 & -1.34 & -5.42 & -3.76 & 1.66 \\
\hline 2 & 642 & 4.97 & $\begin{array}{l}664 \\
725\end{array}$ & 759 & 2401 & 44 & 0.32 & -1.30 & -5.42 & -3.80 & 1.62 \\
\hline 3 & 630 & 4.94 & 670 & 744 & 2432 & 0.4 & 0.34 & -1.28 & -5.44 & -3.82 & 1.62 \\
\hline 4 & 566 & 5.02 & $\begin{array}{l}614 \\
663\end{array}$ & 664 & 2608 & 1 & 0.58 & -1.31 & -5.68 & -3.79 & 1.89 \\
\hline
\end{tabular}

a Measured in $\mathrm{CH}_{2} \mathrm{Cl}_{2}$ solution $\left(\mathrm{c} \approx 10^{-6} \mathrm{M}\right) .{ }^{\mathrm{b}}$ Excitation at the maximum absorption wavelength. ${ }^{\mathrm{c}} \mathrm{OSW} \mathrm{V}$

(Osteryoung square wave voltammetry) value. ${ }^{d}$ HOMO and LUMO energy levels were estimated from OSWV oxidation and reduction curves, respectively, assuming the absolute energy level of ferrocene/ferrocenium to be $5.1 \mathrm{eV}$ below vacuum. e Calculated from $\mathrm{E}_{\mathrm{g}}{ }^{\text {elec }}(\mathrm{eV})=$ E七uмо - Еномо. $_{\text {. }}$

\subsection{Theoretical calculations}

Quantum chemical calculations for the gas phase were carried out in order to gain insight into the electronic structures and molecular energy levels of all new systems (1-4) using density functional theory (DFT) at the B3LYP 6-31G* level with Gaussian 09W. Hexyl side chains were replaced by methyl groups in order to reduce the calculation time. Co-oligomers $\mathbf{1 - 4}$ have high planarity and symmetry for the optimized ground-state geometries (Figure S46, Supporting Information), which should favour the $\pi-\pi$ stacking of the donor molecules.

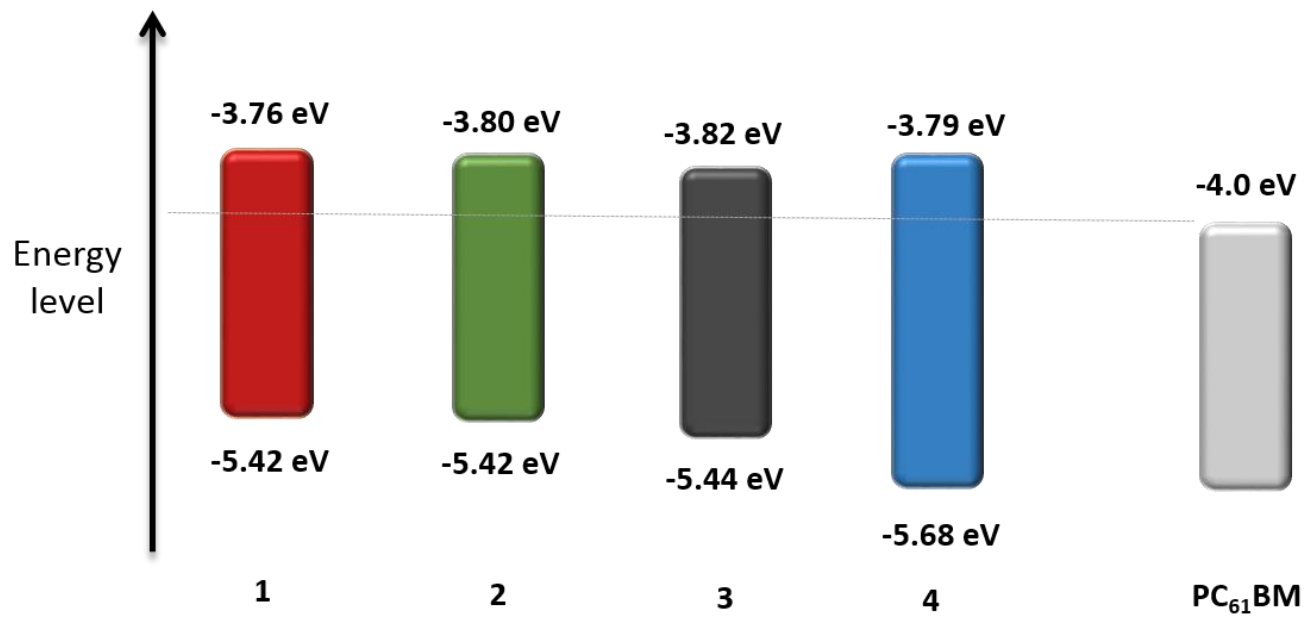

Fig. 3. FMO energy levels and band gap (solid area) of oligomers 1-4 and their relative position to the LUMO with respect to $\mathrm{PC}_{61} \mathrm{BM}$. 
The HOMO electron densities of all co-oligomers 1-4 are mainly localized around the thiophenebased central building block and LUMOs are distributed along the whole molecule, with a preference for the acceptor moieties (Figure 4). The calculated MO energy levels are listed in Table S1 (Supporting Information). Both the experimental and theoretical data show that the new co-oligomers 1-4 display suitable HOMO and LUMO energy values for application as electron-donor materials in $\mathrm{BHJ}$ solar cells using $\mathrm{PC}_{61} \mathrm{BM}$ or $\mathrm{PC}_{71} \mathrm{BM}$ derivatives as electronacceptors, in agreement with the electrochemical data. As predicted from the experimental data, these results highlight that molecule $\mathbf{4}$ will have the highest $V_{O C}$ within this family of derivatives since it has the lowest HOMO value.

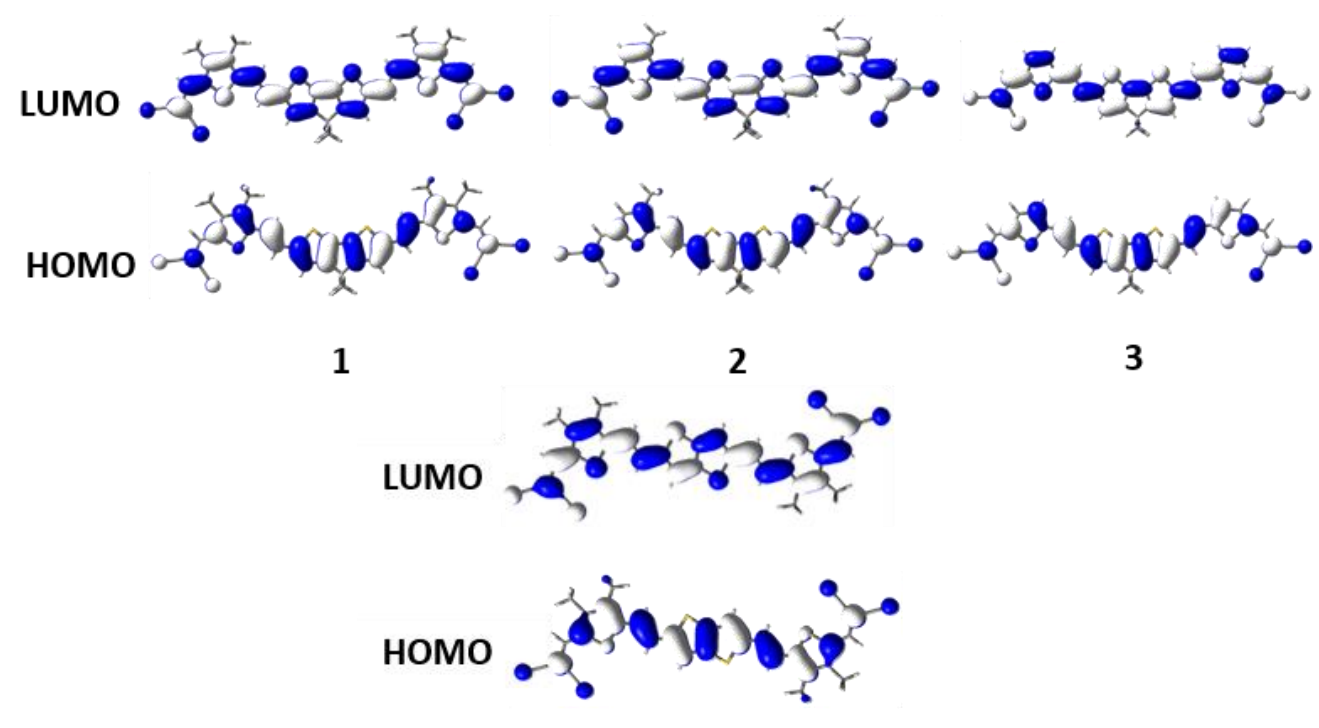

4

Fig. 4. Electronic distribution of the HOMO-LUMO energy levels in co-oligomers 1-4.

\subsection{Photovoltaic properties}

Solution-processed BHJ devices were fabricated using co-oligomers 1-4 as electron donors with a standard device architecture of indium tin oxide (ITO)/PEDOT:PSS/donor:PC ${ }_{61} \mathrm{BM} / \mathrm{LiF} / \mathrm{Al}$ (where $\mathrm{PC}_{61} \mathrm{BM}$ is $[6,6]$-phenyl- $\mathrm{C}_{61}$-butyric acid methyl ester, which was used as electron acceptor material against $\mathrm{PC}_{71} \mathrm{BM}\left([6,6]\right.$-phenyl- $\mathrm{C}_{71}$-butyric acid methyl ester) since poorer results were obtained). The optimal conditions were determined by investigating a range of 
device fabrication parameters, including the solvent, concentration and ratio of the donor:acceptor (blend) solution, spin speed, time for the solvent vapour annealing (SVA) process, and the use of solvent additives. Optimized devices were prepared by spin-coating blended chloroform solutions (total concentration of $15 \mathrm{mg} \mathrm{mL}^{-1}$ ) in the case of co-oligomers $\mathbf{1}$, 2 and 4, whereas tetrachloroethane solution (total concentration of $15 \mathrm{mg} \mathrm{mL}^{-1}$ ) was used for derivative $\mathbf{3}$ due to its poor solubility ( $\mathbf{3}$ only contains two hexyl side chains). Thinner films obtained from more dilute solutions $\left(10 \mathrm{mg} \mathrm{mL}^{-1}\right)$ resulted in lower device performance parameters. All blends were prepared with an excess of the acceptor material (D:A, 1:2 w/w) and all devices were submitted to a solvent vapour annealing (SVA) process using chloroform as solvent. This process resulted in a significant improvement of the final results - with the exception of 4 , where the PCE decreased by about $41 \%$. The current density-voltage $(J-V)$ characteristics and external quantum efficiency (EQE) spectra of the optimized devices for 1-4 are shown in Figures 5 and 6 . The solar cell data are summarized in Table 2.

The devices based on 1:PC ${ }_{61} \mathrm{BM}$ exhibited a relatively high open circuit voltage $\left(V_{O C}\right)$ of $0.91 \mathrm{~V}$, a short-circuit current density $\left(J_{S C}\right)$ of $5.95 \mathrm{~mA} \mathrm{~cm}^{-2}$, a fill factor (FF) of $57 \%$, and a PCE of $3.1 \%$. The solar cell performance was further examined under solvent vapour annealing (SVA) treatment. In OSCs, solvent vapour can penetrate into the blend and lower the glass transition temperature of the materials, thus enabling molecules in blends to gain some mobility to organize into a lower energy state. Thus, according to the findings of Chen and co-workers, good solvents with high vapour pressure lead to the best performances [25]. The devices were optimized by varying the time of the SVA in chloroform and the best result was achieved after 45 s of SVA (Table 2). The device provided an improvement in $J_{S C}$ up to $7.76 \mathrm{~mA} \mathrm{~cm}^{-2}$ and maintained nearly the same $V_{O C}$ $(0.89 \mathrm{~V})$ and FF (57\%) which resulted in a higher PCE of $4.0 \%$ compared to devices before SVA. These results are in agreement with the external quantum efficiency (EQE) measured for all new derivatives, since co-oligomer 1 showed the highest overall value (48\% @ $670 \mathrm{~nm}$ ) within this 
new family of oligomers (Figure 6 (top)) and a notable improvement after the SVA treatment (Figure 6 (bottom)).

Removal of one of the hexyl side chains from each thiophene bridge in $\mathbf{2}$ led to a decrease in the $J_{s C}$ value to $4.30 \mathrm{~mA} \mathrm{~cm}^{-2}$ and in $\mathrm{FF}$ to $33 \%$ resulting in a PCE of $1.3 \%$ generated in the $2: \mathrm{PC}_{61} \mathrm{BM}$ device. Nevertheless, a dramatic improvement was achieved upon applying SVA, with an increase in the $J_{S c}$ value to $6.06 \mathrm{~mA} \mathrm{~cm}^{-2}$, a twofold increase in $\mathrm{FF}$ to $63 \%$, and an increase in the $V_{O C}$ to $0.94 \mathrm{~V}$. The 2:PC ${ }_{61} \mathrm{BM}$ had an enhanced PCE of $3.6 \%$. The solar cell performance of cooligomer $\mathbf{2}$ was also examined by using solvent additives, such as polydimethylsiloxane (PDMS), diiodoctane (DIO), or chloronaphthalene (CN). The use of solvent additives in OSCs can have a substantial effect on the morphology of the active layer and this can lead to enhanced charge collection and transport properties and, therefore, improved efficiencies. In the case of 2: $\mathrm{PC}_{61} \mathrm{BM}$ devices fabricated with the solvent additives, the best results were obtained with a D:A ratio of 2:3 using $0.2 \mathrm{mg} \mathrm{mL}^{-1}$ of PDMS, $5 \mathrm{mg} \mathrm{mL}^{-1}$ of $\mathrm{DIO}$, or $5 \mathrm{mg} \mathrm{mL}^{-1}$ of $\mathrm{CN}$. The photovoltaic results with the solvent additives are presented in Table S2 (Supporting Information). The PCE of the devices prepared with PDMS, DIO, or CN increased from $1.2 \%$ (without any additional additives) to $2.8 \%, 1.5 \%$, and $1.7 \%$, respectively. Nevertheless, these results demonstrate that SVA leads to higher PCEs than the solvent additives in $2: \mathrm{PC}_{61} \mathrm{BM}$ devices. 


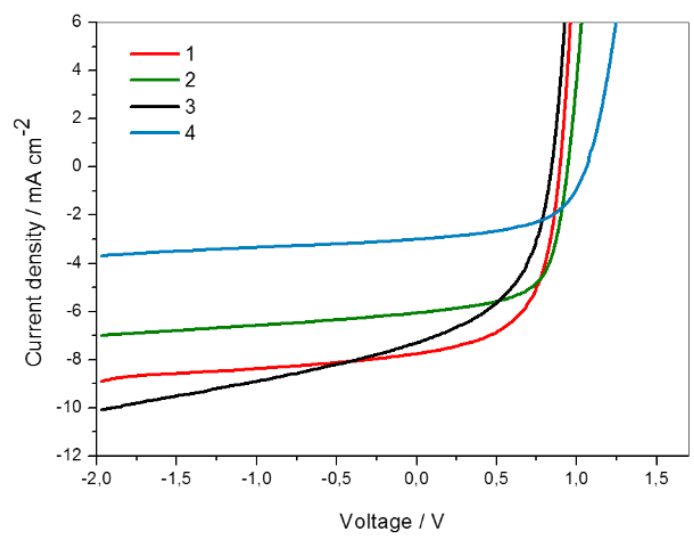

Fig. 5. $J-V$ curves for optimized devices prepared with co-oligomers 1-4 as donors and $\mathrm{PC}_{61} \mathrm{BM}$ as the acceptor measured under standard sun-simulated illumination conditions (AM 1.5G, $100 \mathrm{~mW} \mathrm{~m}^{-2}$ ).

In contrast to the previous co-oligomers 1 and 2, 3: $\mathrm{PC}_{61} \mathrm{BM}$ devices were fabricated in tetrachloroethane as solvent owing to the low solubility of derivative $3\left(0.4 \mathrm{mg} \mathrm{mL}^{-1}\right.$ in chloroform). The photovoltaic results for 3: $\mathrm{PC}_{61} \mathrm{BM}$ devices also exhibited an outstanding improvement upon SVA, from $5.41 \mathrm{~mA} \mathrm{~cm}^{-2}$ to $7.30 \mathrm{~mA} \mathrm{~cm}^{-2}$ in $J_{S c}$, from $38 \%$ to $48 \%$ in $\mathrm{FF}$, and from $1.8 \%$ to $3.0 \%$ in PCE. In contrast to the CPDT-based co-oligomers $\mathbf{1 - 3}$, the devices fabricated using TT-based derivative 4 as the donor gave the best results without SVA. The $J_{S C}$ and the FF decreased from $3.01 \mathrm{~mA} \mathrm{~cm}^{-2}$ and $54 \%$ to $2.51 \mathrm{~mA} \mathrm{~cm}^{-2}$ and $36 \%$, respectively, after SVA. It seems that when the alkyl chains point towards the central building block of the cooligomers, the SVA treatment gives rise to the greatest effect, a situation that was also observed in previous studies [26]. The PCE was 1.7\% and the EQE was the lowest (22\% @ $660 \mathrm{~nm})$. As expected, 4:PC ${ }_{61} \mathrm{BM}$ devices exhibited the highest $V_{O C}$ within this family of co-oligomers, $1.06 \mathrm{~V}$, and this is attributed to the low lying of the HOMO energy level of derivative 4. 


\section{Table 2}

Photovoltaic data for co-oligomers 1-4 before and after SVA measured under standard sun-simulated illumination conditions (AM 1.5G, $\left.100 \mathrm{~mW} \mathrm{~m}^{-2}\right)^{\mathrm{a}}$.

\begin{tabular}{cccccc}
\hline Device & SVA time $(\mathrm{s})$ & $J_{\mathrm{sc}}\left(\mathrm{mA} \mathrm{cm}^{-2}\right)$ & $V_{\mathrm{OC}}(\mathrm{V})$ & $\mathrm{FF}(\%)$ & $\mathrm{PCE}(\%)$ \\
\hline $\mathbf{1}$ & 0 & 5.95 & 0.91 & 57 & 3.1 \\
$\mathbf{1}$ & 45 & 7.76 & 0.89 & 57 & 4.0 \\
$\mathbf{2}$ & 0 & 4.30 & 0.90 & 33 & 1.3 \\
$\mathbf{2}$ & 45 & 6.06 & 0.94 & 63 & 3.6 \\
$\mathbf{3}$ & 0 & 5.41 & 0.88 & 38 & 1.8 \\
$\mathbf{3}$ & 30 & 7.30 & 0.84 & 48 & 3.0 \\
$\mathbf{4}$ & 0 & 3.01 & 1.06 & 54 & 1.7 \\
$\mathbf{4}$ & 30 & 2.51 & 1.08 & 36 & 1.0 \\
\hline
\end{tabular}

a Device structure: ITO/PEDOT:PSS/donor:PC 61 BM/LiF/Al.
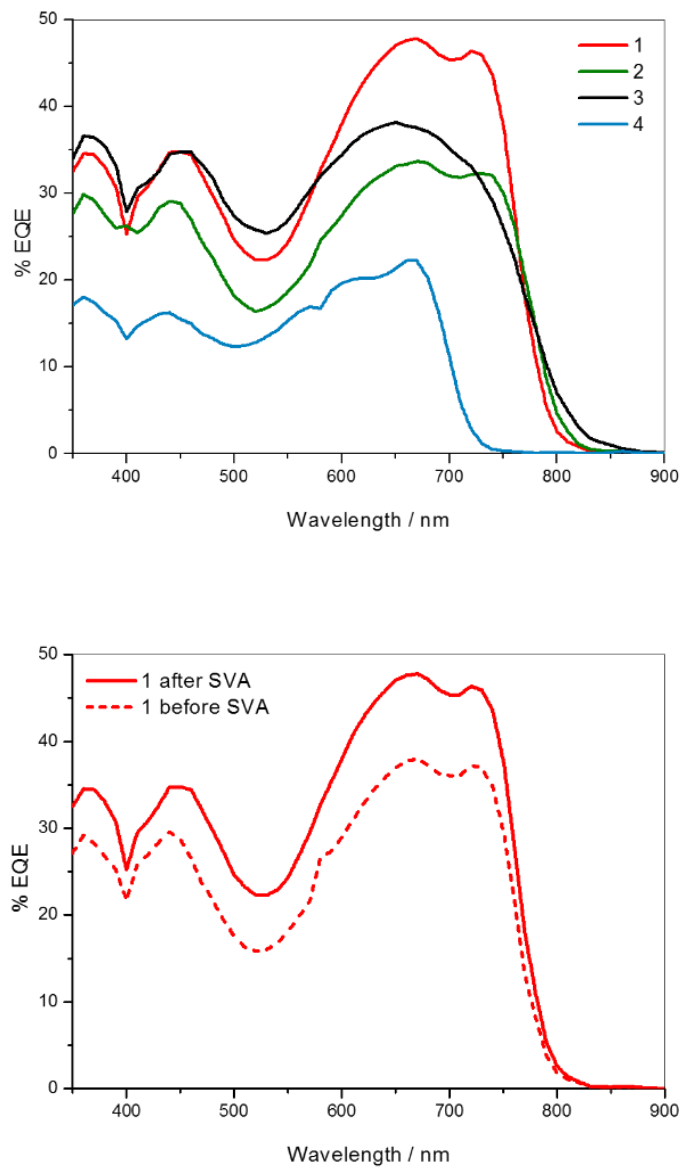

Fig. 6. (top) External quantum efficiency (EQE) spectra of the optimized devices prepared with 1-4 as donor materials and $\mathrm{PC}_{61} \mathrm{BM}$ as acceptor after SVA and (bottom) external quantum efficiency (EQE) spectra of 1:PC ${ }_{61} \mathrm{BM}$ optimized devices before (dotted line) and after (solid line) SVA.

The surface morphologies of $1-4: \mathrm{PC}_{61} \mathrm{BM}$ blend films were investigated by atomic force microscopy (AFM, tapping mode). Each sample was prepared by spin-coating from 
donor:PC ${ }_{61} \mathrm{BM}$ mixed solutions onto ITO/PEDOT:PSS glass surfaces accurately reproducing the photoactive layer of the optimized devices. The topography images of the blends before SVA are shown in Figures $7 \mathrm{a}-\mathrm{d}$ and those after SVA are shown in Figures $7 \mathrm{e}-\mathrm{h}$. The topography roughness of the blended films was obtained from the height images. The AFM phase images are collected in Figures S47-50 (Supporting Information).

Blended surfaces based on co-oligomer 1 (Figures 7 a (before SVA) and 7 e (after SVA)) displayed bundle-like structures both, before and after the SVA process. The morphology after SVA showed an interpenetrated network of fibres, which suggests a good phase separation, wellconnected domains and thus efficient charge generation and charge transfer within the active layer.

Blended surfaces based on $\mathbf{2}$ (Figures 7 b (before SVA) and $7 \mathrm{f}$ (after SVA)) and $\mathbf{3}$ (Figures $7 \mathrm{c}$ (before SVA) and $7 \mathrm{~g}$ (after SVA)), after the SVA process, showed a twofold increase in topography roughness and a regular grain-structured morphology. These features are consistent with a more distinct bi-continuous network of donor and acceptor domains. The increase in surface roughness and phase separation is favourable for exciton dissociation and the interpenetrating pathways for charge transport.

Finally, 4 (Figures $7 \mathrm{~d}$ (before SVA) and $7 \mathrm{~h}$ (after SVA)) exhibited a decrease in surface roughness after the SVA process, probably due to poor film properties of the blend of donor 4 and $\mathrm{PC}_{61} \mathrm{BM}$.

415 The relatively homogeneous morphology and the poor phase separation are unfavourable for charge transfer from the donor to the acceptor and involve high recombination, which in turn limits the $J_{S C}$ and PCE of the resulting device. 

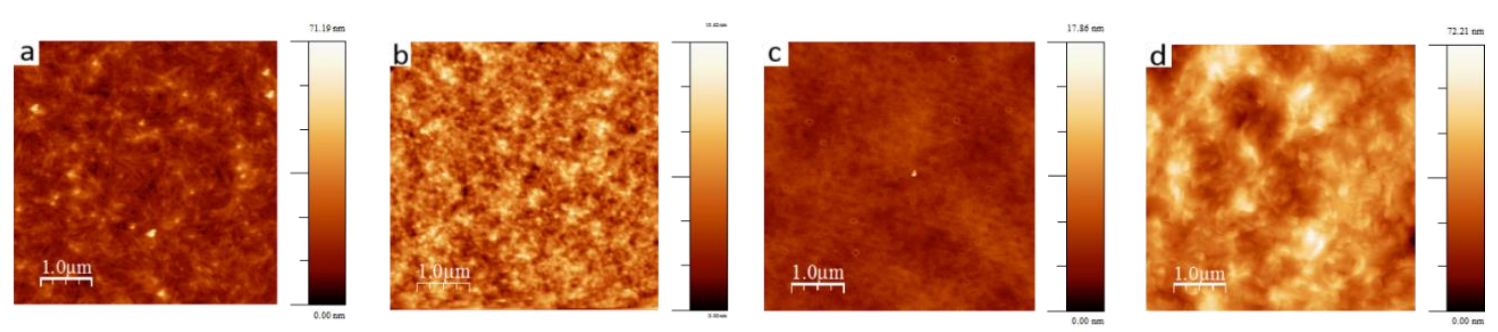

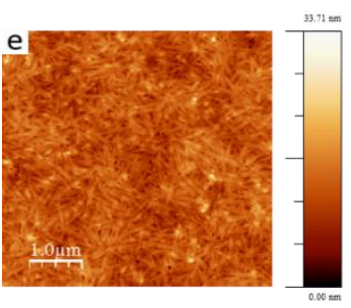

1

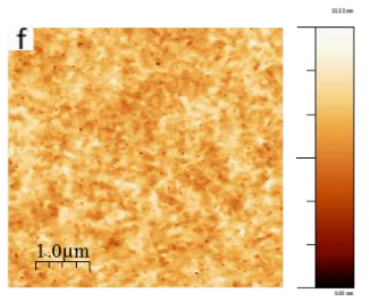

2

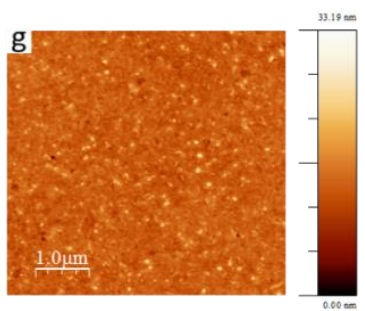

3

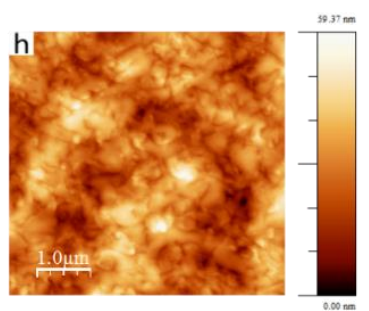

4

Fig. 7. AFM topography images of donor:PC 61 BM blend films on PEDOT:PSS-coated ITO glass substrates, before (a-d) and after (e-h) SVA.

\section{Conclusions}

In summary, we have designed and synthesized a new series of co-oligomers based on cyclopentadithiophene (1-3) or thieno[3,2-b]thiophene (4) as central core linked to different $\beta$ hexyl substituted thiophene rings, and to dicyanovinylene as acceptor groups for applications as electron donor materials in solution-processed BHJ organic solar cells. The optical and electrochemical properties of the CPDT-based derivatives 1-3 were not affected by the $\beta$-alkyl substitution of the thienylenevinylene bridges. Replacement of the CPDT by a TT unit in $\mathbf{4}$ led to a blue-shift in the absorption spectra in solution and thin films, to a significant decrease in the HOMO energy level, and to a slight increase the HOMO-LUMO energy gap. The devices were prepared using the new co-oligomers as electron donors and $\mathrm{PC}_{61} \mathrm{BM}$ as electron acceptor. CPDT-based derivatives showed relatively high efficiencies, ranging from $3.0 \%$ to $4.0 \%$, with the highest PCE of $4.0 \%$ obtained for the highest substituted derivative 1 . With the exception of 4 , the new co-oligomers 1-3 showed a marked improvement in efficiency after SVA, mainly due to the increase in $J_{s c}$ and FF. The effect that SVA had on the morphology of the active layer was also investigated by AFM. Devices based on the acceptor-donor-acceptor structure $\mathbf{4}$ reached the 
highest $V_{O C}$ within this new series of co-oligomers (1.06 V), although the low short-circuit current density $\left(3.01 \mathrm{~mA} \mathrm{~cm}^{-2}\right)$ led to a moderate PCE of 1.7\%. Comparison of $\mathbf{1}$ and $\mathbf{4}$ showed the better ability of the CPDT unit as a central core when compared to TT, since $J_{S C}$ increased by more than double on changing from a TT-based molecule to CPDT-based derivative.

\section{Keywords}

440

Cyclopentadithiophene

Thieno[3,2-b]thiophene

B-Alkyl Substitution

Bulk-heterojunction Solar Cells

Solvent Vapor Annealing

Acknowledgements

We are grateful for financial support from the MINECO, Spain (CTQ2013-48252-P) and Junta de Comunidades de Castilla-La Mancha, Spain (PEII-2014-014-P). RD thanks the Ministerio de Educación, Cultura y Deporte of Spain for a FPU grant.

\section{Appendix A. Supplementary data}

\section{References}

[1] a) Love JA, Nagao I, Huang Y, Kuik M, Gupta V, Takacs CJ, Coughlin JE, Qi L, Van Der Poll TS, Kramer EJ, Heeger AJ, Nguyen TQ, Bazan GC. Silaindacenodithiophene-Based Molecular Donor: Morphological Features and Use in the Fabrication of Compositionally Tolerant, High-Efficiency Bulk Heterojunction Solar Cells. J Am Chem Soc 2014;136:3597-606; b) Love JA, Collins SD, Nagao 455 I, Mukherjee S, Ade H, Bazan GC, Nguyen TQ. Interplay of Solvent Additive Concentration and Active Layer Thickness on the Performance of Small Molecule Solar Cells. Adv Mater 2014;26:7308-16; c) Wessendorf CD, Schulz GL, Mishra A, Kar P, Ata I, Weidelener M, 
Urdanpilleta M, Hanisch J, Mena-Osteritz E, Linden M, Ahlswede E, Bäuerle P. Efficiency Improvement of Solution-Processed Dithienopyrrole-Based A-D-A Oligothiophene BulkHeterojunction Solar Cells by Solvent Vapor Annealing. Adv Energy Mater 2014;4:1400266; d) Walker B, Kim C, Nguyen TQ. Small Molecule Solution-Processed Bulk Heterojunction Solar Cells. Chem Mater 2011;23:470-82; e) Bagnis D, Beverina L, Huang H, Silvestri F, Yao Y, Yan H, Pagani GA, Marks TJ, Facchetti A. Marked Alkyl-vs Alkenyl-Substitutent Effects on Squaraine Dye SolidState Structure, Carrier Mobility, and Bulk-Heterojunction Solar Cell Efficiency. J Am Chem Soc 2010;132:4074-75; f) Roncali J. Molecular Bulk Heterojunctions: An Emerging Approach to Organic Solar Cells. Acc Chem Res 2009;42:1719-30; g) Chen Y, Wan X, Long G. High Performance Photovoltaic Applications Using Solution-Processed Small Molecules. Acc Chem Res 2013;46:2645-55; h) Coughlin JE, Henson ZB, Welch GC, Bazan GC. Design and Synthesis of Molecular Donors for Solution-Processed High-Efficiency Organic Solar Cells. Acc Chem Res 2014;47:257-70.

[2] a) Kan B, Li M, Zhang Q, Liu F, Wan X, Wang Y, Ni W, Long G, Yang X, Feng H, Zuo Y, Zhang M, Huang F, Cao Y, Russell TP, Chen Y. A Series of Simple Oligomer-like Small Molecules Based on Oligothiophenes for Solution-Processed Solar Cells with High Efficiency. J Am Chem Soc 2015;137:3886-93; b) Liu Y, Chen C, Hong Z, Gao J, Yang Y, Zhou H, Dou L, Li G, Yang Y. Solutionprocessed small-molecule solar cells: breaking the $10 \%$ power conversion efficiency. Sci Rep 2013;3:3356; C) Kan B, Zhang Q, Li M, Wan X, Ni W, Long G, Wang Y, Yang X, Feng H, Chen Y. Solution-Processed Organic Solar Cells Based on Dialkylthiol-Substituted Benzodithiophene Unit with Efficiency near 10\%. J Am Chem Soc 2014;136:15529-32; d) Gupta V, Kyaw A, Wang D, Chand S, Bazan GC, Heeger AJ. Barium: An Efficient Cathode Layer for Bulk-heterojunction Solar Cells. Sci Rep 2013;3:1965.

[3] a) Liu Y, Zhao J, Li Z, Mu C, Ma W, Hu H, Jiang K, Lin H, Ade H, Yan H. Aggregation and morphology control enables multiple cases of high-efficiency polymer solar cells. Nat Commun 
2014;5:5293; b) He Z, Xiao B, Liu F, Wu H, Yang Y, Xiao S, Wang C, Russell TP, Cao Y. Singlejunction polymer solar cells with high efficiency and photovoltage. Nat Photonics 2015;9:174-9; c) Yang Y, Chen W, Dou L, Chang WH, Duan HS, Bob B, Li G, Yang Y. High-performance multipledonor bulk heterojunction solar cells. Nat Photonics 2015;9:190-8; d) Liu C, Yi C, Wang K, Yang Y, Bhatta RS, Tsige M, Xiao S, Gong X. Single-Junction Polymer Solar Cells with Over $10 \%$ Efficiency by a Novel Two-Dimensional Donor-Acceptor Conjugated Copolymer. ACS Appl Mater Interfaces 2015;7:4928-35; e) Chen JD, Cui C, Li YQ, Zhou L, Ou QD, Li C, Li Y, Tang JX. SingleJunction Polymer Solar Cells Exceeding 10\% Power Conversion Efficiency. Adv Mater 2015;27:1035-41; f) Subbiah J, Purushothaman B, Chen M, Qin T, Gao M, Vak D, Scholes FH, Chen X, Watkins SE, Wilson GJ, Holmes AB, Wong WWH, Jones DJ. Organic Solar Cells Using a High-Molecular-Weight Benzodithiophene-Benzothiadiazole Copolymer with an Efficiency of 9.4\%. Adv Mater 2015;27:702-5.

[4] a) Mishra A, Bäuerle P. Small Molecule Organic Semiconductors on the Move: Promises for Future Solar Energy Technology. Angew Chem Int Ed 2012;51:2020-67; b) Malytskyi V, Simon JJ, Patrone L, Raimundo JM. Thiophene-based push-pull chromophores for small molecule organic solar cells (SMOSCs). RSC Adv. 2015;5:354-97; c) Ni W, Wan X, Li M, Wang Y, Chen Y. A-D-A small molecules for solution-processed organic photovoltaic cells. Chem Commun 2015;51:4936-50; d) Fitzner R, Mena-Osteritz E, Walzer K, Pfeiffer M, Bäuerle P. A-D-A-Type Oligothiophenes for Small Molecule Organic Solar Cells: Extending the $\pi$-System by Introduction of Ring-Locked Double Bonds. Adv Funct Mater 2015;25:1845-56; e) Wang T, Han L, Wei H, Zhu D, Bao X, Qiao S, Sun W, Chen W, Yang R. Influence of a $\pi$-bridge dependent molecular configuration on the optical and electrical characteristics of organic solar cells. J Mater Chem A 2016;4:8784-92; f) Wang J, Shi K, Suo Y, Lin Y, Yu G, Zhan X. Monodisperse macromolecules based on benzodithiophene and diketopyrrolopyrrole with strong NIR absorption and high mobility. J Mater Chem C 2016;4:3781-91. 
[5] a) Qiu B, Yuan J, Xiao X, He D, Qiu L, Zou Y, Zhang ZG, Li Y. Effect of Fluorine Substitution on Photovoltaic Properties of Alkoxyphenyl Substituted Benzo[1,2-b:4,5-b']dithiophene-Based Small Molecules. ACS Appl Mater Interfaces 2015;7:25237-46; b) Lin Y, Zhan X. Oligomer Molecules for Efficient Organic Photovoltaics. Acc Chem Res 2016;49:175-83; c) Bai HT, Wang YF, Cheng P, Li YF, Zhu DB, Zhan XW. Acceptor-Donor-Acceptor Small Molecules Based on Indacenodithiophene for Efficient Organic Solar Cells. ACS Appl Mater Interfaces 2014;6:842633; d) Li Z, He G, Wan X, Liu Y, Zhou J, Long G, Zuo Y, Zhang M, Chen Y. Solution Processable Rhodanine-Based Small Molecule Organic Photovoltaic Cells with a Power Conversion Efficiency of 6.1\%. Adv Energy Mater 2012;2:74-7; e) Fitzner R, Mena-Osteritz E, Mishra A, Schulz G, Reinold E, Weil M, Korner C, Ziehlke H, Elschner C, Leo K, Riede M, Pfeiffer M, Uhrich C, Bäuerle P. Correlation of $\pi$-Conjugated Oligomer Structure with Film Morphology and Organic Solar Cell Performance. J Am Chem Soc 2012;134:11064-67.

[6] a) Chen Y, Wan X, Long G. High Performance Photovoltaic Applications Using SolutionProcessed Small Molecules. Acc Chem Res 2013;46:2645-55; b) Ni W, Wan X, Li M, Wang Y, Chen Y. A-D-A small molecules for solution-processed organic photovoltaic cells. Chem Commun 2015;51:4936-50; c) Wetzel C, Mishra A, Mena-Osteritz E, Walzer K, Pfeiffer M, Bäuerle P. Development of strongly absorbing $\mathrm{S}, \mathrm{N}$-heterohexacene-based donor materials for efficient vacuum-processed organic solar cells. J Mater Chem C 2016;4:3715-25; d) Kan B, Li M, Zhang Q, Liu F, Wan X, Wang Y, Ni W, Long G, Yang X, Feng H, Zuo Y, Zhang M, Huang F, Cao Y, Russell TP, Chen Y. A Series of Simple Oligomer-like Small Molecules Based on Oligothiophenes for SolutionProcessed Solar Cells with High Efficiency. J Am Chem Soc 2015;137:3886-93; e) Zhang Q, Kan B, Liu F, Long G, Wan X, Chen X, Zuo Y, Ni W, Zhang H, Li M, Hu Z, Huang F, Cao Y, Liang Z, Zhang M, Russell TP, Chen Y. Small-molecule solar cells with efficiency over 9\%. Nat Photonics 2015;9:35-41. 
[7] a) Lin Y, Wang J, Zhang ZG, Bai H, Li Y, Zhu D, Zhan X. An Electron Acceptor Challenging Fullerenes for Efficient Polymer Solar Cells. Adv Mater 2015;27:1170-74; b) Wang C, Dong H, Hu W, Liu Y, Zhu D. Semiconducting $\pi$-Conjugated Systems in Field-Effect Transistors: A Material Odyssey of Organic Electronics. Chem Rev 2012;112:2208-67; c) Cheng YJ, Wu JS, Shih PI, Chang CY, Jwo PC, Kao WS, Hsu CS. Carbazole-Based Ladder-Type Heptacylic Arene with Aliphatic Side Chains Leading to Enhanced Efficiency of Organic Photovoltaics. Chem Mater 2011;23:2361-69; d) Verstappen P, Cardinaletti I, Vangerven T, Vanormelingen W, Verstraeten F, Lutsen L, Vanderzande D, Manca J, Maes W. Impact of Structure and Homo-Coupling of the Central Donor Unit of Small Molecule Organic Semiconductors on Solar Cell Performance. RSC Adv 2016;6:32298-307.

[8] a) Fitzner R, Elschner C, Weil M, Uhrich C, Körner C, Riede M, Leo K, Pfeiffer M, Reinold E, Mena-Osteritz E, Bäuerle P. Interrelation between Crystal Packing and Small-Molecule Organic Solar Cell Performance. Adv Mater 2012;24:675-80; b) Wessendorf CD, Perez-Rodriguez A, Hanisch J, Arndt AP, Ata I, Schulz G, Quintilla A, Bäuerle P, Lemmer U, Wochner P, Ahlswede E, Barrena E. Understanding the effect of solvent vapor annealing on solution-processed A-D-A oligothiophene bulk-heterojunction solar cells: the role of alkyl side chains. J Mater Chem. A 2016;4:2571-80; c) Fitzner R, Mena-Osteritz E, Mishra A, Schulz G, Reinold E, Weil M, Körner C, Ziehlke H, Elschner C, Leo K, Riede M, Pfeiffer M, Uhrich C, Bäuerle P. Correlation of $\pi$ Conjugated Oligomer Structure with Film Morphology and Organic Solar Cell Performance. J Am Chem Soc 2012;134:11064-7.

[9] a) Coppo P, Turner ML. Cyclopentadithiophene based electroactive materials. J Mater Chem 2005;15:1123-33; b) Tang T, Lin T, Wang F, He C. A new aspect of cyclopentadithiophene based polymers: narrow band gap polymers upon protonation. Chem Commun 2015;51:13229-32; c) Li XC, Sirringhaus H, Garnier F, Holmes AB, Moratti SC, Feeder N, Clegg W, Teat SJ, Friend RH. A Highly $\pi$-Stacked Organic Semiconductor for Thin Film Transistors Based on Fused Thiophenes. 
J Am Chem Soc 1998;120:2206-7; d) Popere BC, Della Pelle AM, Poe A, Balaji G, Thayumanavan S. Predictably tuning the frontier molecular orbital energy levels of panchromatic low band gap BODIPY-based conjugated polymers. Chem Sci 2012;3:3093-102; e) Belén Marco A, Martínez N, Franco S, Garín J, Orduna J, Villacampa B, Revuelto A, Andreu R. Dithienopyrrole as a Rigid Alternative to the Bithiophene $\pi$ Relay in Chromophores with Second-Order Nonlinear Optical Properties. Chem Asian J 2015;10:188-97; f) Chang SW, Horie M. A donor-acceptor conjugated block copolymer of poly(arylenevinylene)s by ring-opening metathesis polymerization. Chem Commun 2015;51:9113-6.

565 [10] a) Jung IH, Yu J, Jeong E, Kim J, Kwon S, Kong H, Lee K, Woo HY, Shim HK. Synthesis and Photovoltaic Properties of Cyclopentadithiophene-Based Low-Bandgap Copolymers That Contain Electron-Withdrawing Thiazole Derivatives. Chem - Eur J 2010;16:3743-52; b) Gao P, Cho D, Yang X, Enkelmann V, Baumgarten M, Müllen K. Heteroheptacenes with Fused Thiophene and Pyrrole Rings. Chem Eur J 2010;16:5119-28; c) Zhang M, Tsao HN, Pisula W, Yang C, Mishra

570 A, Müllen K. Field-Effect Transistors Based on a Benzothiadiazole-Cyclopentadithiophene Copolymer. J Am Chem Soc 2007;129:3472-3.

[11] a) Chai Q, Li W, Wu Y, Pei K, Liu J, Geng Z, Tian H, Zhu W. Effect of a Long Alkyl Group on Cyclopentadithiophene as a Conjugated Bridge for $D-A-\pi-A$ Organic Sensitizers: IPCE, Electron Diffusion Length, and Charge Recombination. ACS Appl Mater Interfaces 2014;6:14621-30; b)

575 Chang SW, Kettle J, Waters H, Horie M. Cyclopentadithiophene-benzothiadiazole copolymers with permutations of repeating unit length and ratios; synthesis, optical and electrochemical properties and photovoltaic characteristics. RSC Adv 2015;5:107276-84; c) Wang K, Firdaus Y, Babics M, Cruciani F, Saleem Q, Labban A, Alamoudi M, Marszalek T, Pisula W, Laquai F, Beaujuge P. $\pi$-Bridge-Independent 2-(Benzo[c] $[1,2,5]$ thiadiazol-4-ylmethylene)malononitrile-Substituted Nonfullerene Acceptors for Efficient Bulk Heterojunction Solar Cells. Chem Mater 2016;28:22008. 
[12] a) Wang T, Han L, Wei H, Zhu D, Bao X, Qiao S, Sun W, Chen W, Yang R. Influence of a $\pi-$ bridge dependent molecular configuration on the optical and electrical characteristics of organic solar cells. J Mater Chem A 2016;4:8784-92; b) Zuo GZ, Li ZJ, Zhang MJ, Guo X, Wu Y, Zhang SQ,

Peng B, Wei W, Hou JH. Influence of the backbone conformation of conjugated polymers on morphology and photovoltaic properties. Polym Chem 2014;5:1976-81; c) Liu S, Bao X, Li W, Wu K, Xie G, Yang R, Yang C. Benzo[1,2-b:4,5- $\left.b^{\prime}\right]$ dithiophene and Thieno[3,4-c]pyrrole-4,6-dione Based Donor- $\pi$-Acceptor Conjugated Polymers for High Performance Solar Cells by Rational Structure Modulation. Macromolecules 2015;48:2948-57; d) Wei H, Chen WC, Han LL, Wang T, Bao XC, Li XY, Liu J, Zhou YH, Yang RQ. A Solution-Processable Molecule using Thieno[3,2b]thiophene as Building Block for Efficient Organic Solar Cells. Chem -Asian J 2015;10:1791-98; e) Pelleja L, Domínguez R, Aljarilla A, Clifford JN, de la Cruz P, Langa F, Palomares E. Use of Thienylenevinylene and Ethynyl Molecular Bridges in Organic Dyes for Dye-Sensitized Solar Cells: Implications for Device Performance. ChemElectroChem 2014;1:1126-29. B, Donnio B, Sanaur S, Lacaze E, Fave JL, Matczyszyn K, Samoc M, Wu JW, Attias AJ, Ribierre JC, Mathevet F. Charge carrier mobility study of a mesogenic thienothiophene derivative in bulk and thin films. Org Electron 2014:15:943-53; b) Heeney M, Bailey C, Genevicius K, Shkunov M, Sparrowe D, Tierney S, McCulloch I. Stable Polythiophene Semiconductors Incorporating Thieno[2,3-b]thiophene. J Am Chem Soc 2005;127:1078-9.

[14] Cheng YJ, Yang SH, Hsu CS. Synthesis of Conjugated Polymers for Organic Solar Cell Applications. Chem Rev 2009;109:5868-923.

[15] a) Bronstein H, Chen Z, Ashraf RS, Zhang W, Du J, Durrant JR, Tuladhar PS, Song K, Watkins SE, Geerts Y, Wienk MM, Janssen RA, Anthopoulos T, Sirringhaus H, Heeney M, McCulloch I. Thieno[3,2-b]thiophene-Diketopyrrolopyrrole-Containing Polymers for High-Performance Organic Field-Effect Transistors and Organic Photovoltaic Devices. J Am Chem Soc 
2011;133:3272-5; b) Xu YX, Chueh CC, Yip HL, Ding FZ, Li YX, Li CZ, Li X, Chen WC, Jen AKY. Improved Charge Transport and Absorption Coefficient in Indacenodithieno[3,2-b]thiophenebased Ladder-Type Polymer Leading to Highly Efficient Polymer Solar Cells. Adv Mater 2012;24:6356-61.

[16] a) Zhang L, Liu F, Diao Y, Marsh HS, Colella NS, Jayaraman A, Russell TP, Mannsfeld SC, Briseno AL. The Good Host: Formation of Discrete One-Dimensional Fullerene "Channels" in Well-Ordered Poly(2,5-bis(3-alkylthiophen-2-yl)thieno[3,2-b]thiophene) Oligomers. J Am Chem Soc 2014;136:18120-30; b) Deng D, Shen S, Zhang J, He C, Zhang Z, Li Y. Solution-processable star-shaped photovoltaic organic molecule with triphenylamine core and thieno[3,2b]thiophene-dicyanovinyl arms. Org Electron 2012;13:2546-52.

[17] Sorohhov G, Yi C, Grätzel M, Decurtins S, Liu SX. A hybrid electron donor comprising cyclopentadithiophene and dithiafulvenyl for dye-sensitized solar cells. Beilstein J Org Chem 2015;11:1052-9.

[18] Roncali J. Oligothienylenevinylenes as a New Class of Multinanometer Linear $\pi$-Conjugated Systems for Micro- and Nanoelectronics. Acc Chem Res 2000;33:147-56.

[19] Montcada NF, Domínguez R, Pelado B, de la Cruz P, Palomares E, Langa F. High photocurrent in oligo-thienylenevinylene-based small molecule solar cells with $4.9 \%$ solar-to-electrical energy conversion. J Mater Chem A 2015;3:11340-8.

625 [20] Zheng S, Barlow S, Parker TC, Marder SR. A convenient method for the synthesis of electronrich phosphonates. Tetrahedron Lett 2003;44:7989-92.

[21] Domínguez R, Fernandez-Montcada N, de la Cruz P, Palomares EJ, Langa F. Cyclopentadithiophene organic core in small molecule organic solar cells: morphological control of carrier recombination. Phys Chem Chem Phys 2017;19:3640-8. 

Skabara PJ. Linearly extended tetrathiafulvalene analogues with fused thiophene units as $\pi$ conjugated spacers. J Mat Chem 2003;13:1324-32.

[23] Spano FC. The Spectral Signatures of Frenkel Polarons in H- and J-Aggregates. Acc Chem Res 2010;43:429-39.

635 [24] Cardona CM, Li W, Kaifer AE, Stockdale D, Bazan GC. Electrochemical Considerations for Determining Absolute Frontier Orbital Energy Levels of Conjugated Polymers for Solar Cell Applications. Adv Mater 2011;23:2367-71.

[25] Li M, Liu F, Wan X, Ni W, Kan B, Feng H, Zhang Q, Yang X, Wang Y, Zhang Y, Shen Y, Russell TP, Chen Y. Subtle Balance Between Length Scale of Phase Separation and Domain Purification 640 in Small-Molecule Bulk-Heterojunction Blends under Solvent Vapor Treatment. Adv Mater 2015;27:6296-302.

[26] Weidelener M, Wessendorf CD, Hanisch J, Ahlswede E, Götz G, Lindén M, Schulz G, MenaOsteritz E, Mishra A, Bäuerle P. Dithienopyrrole-Based Oligothiophenes for Solution-Processed Organic Solar Cells. Chem Commun 2013;49:10865-7. 